\title{
USAGE PATTERN OF HOUSEHOLD DRINKING WATER IN DIARRHEA IN LAND OF BUMBU YEAR 2016
}

\author{
Dicky Andiarsa ${ }^{1}$, Syarif Hidayat ${ }^{1}$, Ika Setianingsih ${ }^{1}$ \\ ${ }^{1}$ Tanah Bambu of Research and Development Center, Batulicin, Kalimantan Selatan, Indonesia \\ Correspondence Address: Dicky Andiarsa \\ Email: andiarsa@gmail.com
}

\begin{abstract}
Diarrhea has been long a public health concern in the world especially to infants and children. Diarrhea can be caused by many factors including sanitation, clean and healthy behavior, and access to clean water, consumption of drinking water and food, and so on. The results of the research in Tanah Bumbu Regency stated that some of the main causes related to the incidence of diarrhea in Tanah Bumbu Regency included Sanitation, Healthy and clean behavior, clean water access, and drinking water access. Secondary data analysis held to define the scheme of drinking water consumption in families with diarrhea patients in Tanah Bumbu Regency. The result showed that the most families with diarrhea consumed refill drinking water $(67.06 \%)$ with most of them did not do any pre-treatment to the water $(81.55 \%)$. The water consuming pattern has been changed to community of Tanah Bumbu Regency by consuming refilling water. Processing (boiling) refilling water before drinking can reduce the risk of diarrhea.
\end{abstract}

Keywords: refilling drinking water, diarrhea, drinking water consumption patterns

\begin{abstract}
ABSTRAK
Diare merupakan permasalahan kesehatan masyarakat di dunia sejak lama terutama pada bayi dan anak-anak. Diare dapat diakibatkan oleh banyak faktor antara lain sanitasi, perilaku hidup bersih dan sehat (PHBS), akses air bersih, perilaku konsumsi air minum dan makanan, dan sebagainya. Hasil penelitian di Kabupaten Tanah Bumbu (501 responden) menyebutkan bahwa beberapa penyebab utama terkait kejadian diare di Kabupaten Tanah Bumbu antara lain Sanitasi, PHBS, Akses air bersih, dan Akses air minum. Studi analisis lanjut ini dilakukan untuk menentukan pola penggunaan air minum pada keluarga penderita diare di Kabupaten Tanah Bumbu. Hasil menunjukkan bahwa sebagian besar keluarga penderita diare mengkonsumsi air minum isi ulang $(67,06 \%)$ dan sebagian besar mereka tidak mengolah airnya sebelum diminum (81,55\%). Telah terjadi perubahan pola penggunaan sumber air minum di Kabupaten Tanah Bumbu yaitu air minum isi ulang. Mengolah (merebus) air isi ulang sebelum diminum dapat mengurangi risiko diare.
\end{abstract}

Kata Kunci: Air isi ulang, diare, pola konsumsi air minum

\section{INTRODUCTION}

Diarrhea has long been a issue of public health issues in the world especially on poor and developing countries. Diarrhea contributed $18 \%$ as the cause of death of children under 5 years (Farthing et al. 2013), and children in developing countries can suffer from diarrhea up to 10 times a year (Vandepitte et al. 2011). South Kalimantan has an incidence of diarrhea $3.3 \%$ in 2013 and the incidence of diarrhea at Tanah Bumbu District in 2013 reached 1.7\% (Litbangkes 2014), and the prevalence of diarrhea in children aged 1-4 years reached $17,17 \%$ (Ministry of Health 2008).

Diarrhea can be caused by many factors, among others, sanitation (Farthing et al. 2013)(Cairncross \& Valdmanis 2006), clean and healthy life conduct (PHBS) (Huda et al. 2012), Clean Water Access (Godana \& Mangiste 2013), consumption behaviour of drinking water and Food (Bwogi et al. 2016), and so on. Lack of environmental sanitation surveillance data on the cause of diarrhea resulted in weak cases of premature diarrhea detection of both causes and targets vulnerable to this case especially in 
childhood and seniors. This is becoming one of the factors that cause program delays to take preventive response in more widespread cases.

The result of analysis of the research factors causing diarrhea in land of Bumbu District conducted by Balai Litbangkes soil Bumbu in the year 2016 mention that some of the main causes related to the incidence of diarrhea in land of Bumbu district among others sanitation, PHBS, access to Clean water and drinking water (Andiarsa, Setianingsih, Setyaningtyas, et al. 2016)). Based on research integrated with spatial analysis shows that diarrhea often appears centered in areas with polluted water sources. (Traoré et al. 2013) The above shows that poor quality of drinking water can determine the quality of one's health. Information related to how the community has access to drinking water and information on how management is important to discuss. This is the cornerstone of further analysis studies conducted to know more in the pattern of drinking water consumption in the family of diarrhea sufferers in Tanah Bumbu district.

Drinking water access seems to have undergone a paradigm change in its access and processing. (Sima et al. 2012) Modern society has a tendency to choose comfort and practicality in living the life. (Wong \& Mui 2008) One of them is drinking water, in developing countries such as Indonesia, for people with upper middle economic status tend to buy readyto-drink water in packaging, or that has a good piping system (Mekonnen \& Hoekstra 2014) while Conversely, people with middle and lower economic status still choose drinking water either from groundwater and water well (Majuru et al. 2012).

In recent years there has been a solution to get drinking water with a more convenient and affordable method of drinking water (DAM) (Sima et al. 2012). This business offers the water in the claims ready to drink with some technology screening and ultraviolet Illumination (UV) (Sima \& Elimelech 2013). DAMpun products are sold at relatively affordable prices in the wider community (Walter $e t$ al. 2017). This effort has been marbling in decades so it is thought to cause the shifting trend of public access patterns to the daily drinking water of their households.

Whether this drinking water is safe for immediate consumption should still be studied and researched deeper. Some studies have mentioned that drinking water is safe, (Kurniatri 2011), but others call this drinking water unworthy. (Keman 2005; Wandrivel et al. 2012; Tombeng et al. 2013; Apriliana et al. 2014; Birawida et al. 2018) regardless of the type of drinking water that is accessed by the community, the health problems that can be caused by this water consumption is not separated from how the society gets, stores, and processing it before Drink.

\section{METHODS}

This study is an analysis of advanced analyses of secondary data from the research "analysis of the cause of diarrhoea factors in Tanah Bumbu District with the approach of Geographical Information System (GIS)" by Dicky Andiarsa, Ika Setianingsih, Syarif Hidayat, Dian Eka Setyaningtyas, et al. in 2016 who have obtained the ethics permit from the health R \&amp; D Agency, Ministry of Health Republic of Indonesia with number LB. 02.01/5.2/TO. 235/2016. (Andiarsa, Setianingsih, Setyaningtyas, et al. 2016; Andiarsa et al. 2017; Andiarsa et al. 2018) The secondary Data obtained comes from a latitude study with observation methods, interviews, and household water checks. The use of data for this analysis include data on household characteristics of sufferers and behaviors as well as how to process drinking water in households consisting of several interview and observation questions that had previously 
been given explanation and Following the study's approval by signing informed consent.

Additional Data is obtained from the test results of the test water supply of some drinking water in the district Pagatan , Bumbu land, as one of the research areas in this study. All of the Depo drinking water contained in the town of Pagatan (43 Depo) is sampled water products and carried out a bit of interviews and observations on the operator. Refill drinking water check is done in laboratory of microbiology of soil Litbangkes Hall with Most Probable Number (MPN) and Total Plaque Count (TPC) methods to determine the level of contamination coliform in water. The certificate of examination result was submitted to the Kab Health office. Land of Bumbu No. LB. $02.03 / 3 / 620 / 2018$ as a material report and recommendation.

In the process of analysis, water resources are determined for household drinking water. This type of shielded water is defined as water that has a tightly sealed water source and/or has a network. Good and small channel installation is likely to be contaminated from the outside. The type of unshielded water is water that has a place of source that is not tightly sealed and/or has an un-good installation network and is likely to be contaminated from the outside. This definition can be illustrated in Table 1.

Table 1. Categorizing of the type of source of household drinking water

\begin{tabular}{ll}
\hline Drinking water source & Type \\
\hline Bottled water & Protected \\
Refill water & Unprotected \\
Water TAPS & Protected \\
Wells drill & Protected \\
Protected Wells & Protected \\
Unprotected Wells & Unprotected \\
Rainwater containers & Unprotected \\
Water river/Lake/irrigation & Unprotected \\
\hline
\end{tabular}

Source: Research "analysis of diarrhea-causing factors in land of Bumbu District with Geographical Information System (GIS) approach"

As for the depo of drinking water is categorized as an unprotected source of water because of the observation on the provider of refill drinking water still do not meet the minimum requirements in the water supply service process from both aspects of water resources The service process and the operation of the tool are still substandard.

The data in this research were obtained in the form of nominal data include data on household characteristics and sufferers, data on drinking water resources, and data on how to manage drinking water. Numerical Data is the result of water laboratory test from Depo drinking water. Determination of the number of samples of respondents obtained by stratified random sampling in the population of all diarrhea sufferers listed in the selected Puskesmas and the Depo drinking water by the total sampling. The collected data set was analyzed descriptively using the Chi Square method and logistical regression to determine the efficacy and relative risks associated with access and the use of drinking water for households. Data of Depo inspection of drinking water as a coupling data for the data of the type of household water sources and how to manage it.

\section{RESULTS}

Data analysis results show
interviews made to 501 selected respondents regarding the source of drinking water obtained mostly from refillable drinking water sources purchased at the Depo refill drinking water near the respondent's residence. The number of depo use of drinking water includes very large proportions compared to other drinking water sources. 
Table 2. Distribution of drinking water sources

\begin{tabular}{lrr}
\hline Drinking water source & N & \% \\
\hline Bottled water & 9 & 1,79 \\
Refill water & 336 & 67,06 \\
Water TAPS & 56 & 11,18 \\
Wells drill & 5 & 0,99 \\
Protected Wells & 17 & 3,39 \\
Unprotected Wells & 46 & 9,18 \\
Rainwater containers & 3 & 0,59 \\
Water river/Lake/irrigation & 29 & 5,79 \\
\hline Amount & 501 & 100 \\
\hline
\end{tabular}

Table 2 shows the source of drinking water from the depo of drinking water consumed by respondents. They bought the water in a depo drinking water close to their house. However, there are still some respondents who use rainwater and river water sources as their drinking water, although there are many alternatives to drinking water.

Table 3. Sources of drinking water

\begin{tabular}{|c|c|c|c|c|c|c|c|c|c|c|}
\hline \multirow[b]{2}{*}{$\begin{array}{c}\text { Age } \\
\text { suffer } \\
\text { er }\end{array}$} & \multicolumn{8}{|c|}{ Types of drinking water sources } & \multirow{2}{*}{$\begin{array}{c}\text { Amo } \\
\text { unt }\end{array}$} & \multirow{2}{*}{$\begin{array}{c}P- \\
\text { valu } \\
\text { e }\end{array}$} \\
\hline & $\begin{array}{c}\text { Bottl } \\
\text { ed } \\
\text { water }\end{array}$ & $\begin{array}{c}\text { Refi } \\
\text { ll } \\
\text { wat } \\
\text { er }\end{array}$ & $\begin{array}{c}\text { Wate } \\
\mathbf{r} \\
\text { TAPS }\end{array}$ & $\begin{array}{l}\text { Wells } \\
\text { drill }\end{array}$ & $\begin{array}{c}\text { Prote } \\
\text { cted } \\
\text { Wells }\end{array}$ & $\begin{array}{c}\text { Unpr } \\
\text { otecte } \\
\text { d } \\
\text { Wells }\end{array}$ & $\begin{array}{c}\text { Rainwate } \\
\mathbf{r} \\
\text { containers }\end{array}$ & $\begin{array}{c}\text { Wate } \\
\mathbf{r} \\
\text { river/ } \\
\text { Lake/ } \\
\text { irriga } \\
\text { tion }\end{array}$ & & \\
\hline $\begin{array}{l}0-5 \\
\text { years }\end{array}$ & 3 & 158 & 21 & 2 & 2 & 19 & 1 & 8 & 214 & $\begin{array}{c}0,00 \\
1\end{array}$ \\
\hline $\begin{array}{l}6-15 \\
\text { years }\end{array}$ & 1 & 60 & 7 & 0 & 8 & 15 & 1 & 3 & 95 & \\
\hline $\begin{array}{l}16-55 \\
\text { years }\end{array}$ & 5 & 104 & 21 & 2 & 5 & 8 & 1 & 12 & 158 & \\
\hline $\begin{array}{l}\geq 56 \\
\text { years }\end{array}$ & 0 & 14 & 7 & 1 & 2 & 4 & 0 & 6 & 34 & \\
\hline $\begin{array}{l}\text { Amou } \\
\text { nt }\end{array}$ & 9 & 336 & 56 & 5 & 17 & 46 & 3 & 29 & 501 & \\
\hline
\end{tabular}

The use of drinking water from the depo of drinking water has been widespread in various communities and age groups. Table 3 describes the age of some diarrhea and what types of drinking water sources are consumed every day. Results showed that people with age of 0-5 years mostly consume refill water as a source of drinking water followed by the 
Dicky Andiarsa dan Syarif Hidayat, Usage Pattern of Household... 5

productive age (16-55 years) with a very significant difference with the other age

group $(P$-value $=$

$0.001)$

Table 4. Distribution of drinking water sources of diarrhea and processing

\begin{tabular}{lcccccc}
\hline \multirow{2}{*}{$\begin{array}{c}\text { Types of drinking water } \\
\text { sources }\end{array}$} & $\begin{array}{l}\text { Pooke } \\
\text { d }\end{array}$ & $\begin{array}{l}\text { Illumina } \\
\text { ted }\end{array}$ & Filtered & $\begin{array}{l}\text { Not } \\
\text { Processed }\end{array}$ & $\begin{array}{c}\text { Amou } \\
\text { nt }\end{array}$ & $\boldsymbol{p}$-value \\
\hline Bottled water & 3 & 1 & 0 & 5 & 9 & 0,0000 \\
Refill water & 51 & 8 & 3 & 274 & 336 & 1 \\
Water TAPS & 51 & 1 & 2 & 2 & 56 & \\
Wells drill & 4 & 0 & 0 & 1 & 5 & \\
Protected Wells & 13 & 1 & 2 & 1 & 17 & \\
Unprotected Wells & 44 & 0 & 0 & 2 & 46 & \\
Rainwater containers & 3 & 0 & 0 & 0 & 3 & \\
Water river/Lake/irrigation & 24 & 5 & 0 & 0 & 29 & \\
\hline Amount & 197 & 16 & 7 & 285 & 501 & \\
\hline
\end{tabular}

Table 4 shows how the respondent processed his drinking water source before consumption. The above data stated that about $57 \%$ of diarrhea sufferers have the habit of not processing drinking water before consumption, especially the source of drinking water in the form of water from the Depo water that is largely not processed at all and directly consumed. Different things are shown in respondents who use drinking water from other sources where most of them cook their water before drinking. Results showed a very significant difference $(\mathrm{P}$-value $=0,0000)$.

In this study we also conducted quotation tests by taking water samples from the Depo drinking water in the Pagatan region (one of the research areas) for us to check coliform contamination rate. Results showed in table 5 that of the 42 depo that we check, 23 Depo The water is declared positive coliform and is not feasible to be consumed directly based on WHO provisions about the quality standards of drinking water. (WHO \& UNICEF 2015) However, this product is still safe to consume and reduce the risk of contamination during water management at household level e.g. boiled. (Clasen 2015).

Table 5. Results of bacteriological Examination in Depo drinking water refill in Pagatan area

\begin{tabular}{cccc}
\hline $\begin{array}{c}\text { Number of } \\
\text { Depo }\end{array}$ & Test result & $\begin{array}{c}\text { Mean of MPN } \\
(\text { MPN/100ml) }\end{array}$ & $\begin{array}{c}\text { Mean of TPC } \\
\text { (CFU/ml) }\end{array}$ \\
\hline 19 & Negatif & 0 & 0 \\
23 & Positif & $6.087(0 \leq \mu \geq 38)$ & 297.420 \\
\hline
\end{tabular}


The source of household drinking water obtained by the community experienced some conditions in the community before consumption. Sources of drinking water are processed first and not processed at all and directly consumed.
Table 6 is the result of a regression analysis that shows that of all diarrhea sufferers who have an unprotected type of water source has a tendency of 14 times not to treat the drinking water first before consumption.

Table 6. Treatment of household drinking water diarrhea sufferer

\begin{tabular}{|c|c|c|c|c|}
\hline $\begin{array}{l}\text { Types of drinking } \\
\text { water sources }\end{array}$ & Processed & UnProcessed & Odd Ratio & CI 95\% \\
\hline Protected & 62 & 8 & 13,94 & $6,50-29,87$ \\
\hline UnProtected & 154 & 277 & & \\
\hline
\end{tabular}

\section{DISCUSSION}

Depo drinkable drinking water has emerged in the regency of Tanah Bumbu as one of the alternatives to provide practical and economical drinking water. (Andiarsa, Setianingsih, Fadilly, et al. 2016) In Parimin Research (2016) a number of elements that have significantly increased the need for drinking water refill, among which are more affordable price, mineral drinking water, and the number of members Families, and the amount of household income. (Parimin et al. 2016) Changes in household drinking water access behaviour are influenced by factors such as gender, poverty, stigma, comfort, and local social sturcture. (Lucas et al. 2011) The practicality and ease of getting this water is the main cause for the community to choose and consider the use of refill type water source.

Some studies have shown that drinking water from the depo of drinking water can cause several diseases and can partially harm the human being consume it, (Keman 2005; Wandrivel et al. 2012; Tombeng et al. 2013; Rumondor et al. 2014; Apriliana et al. 2014; Birawida et al. 2018) While the economic viewpoint mentioning the depo business of drinking water can be a major source of income for small entrepreneurs. (Bayer 2013; Andiarsa et al. 2018)
The number of diarrhea sufferers in the Children group shows the range of these groups against infections of an ungood consumption pattern. Results showed that most sufferers besides children were also of productive age. Most of the respondents were young families who had more frequent activities outside the House and had high busyness to be the main reason for their use of refill drinking water so that the family of people chose a refill drinking water source The majority of the sufferer is a productive toddler and adult. This is in accordance with research in Sudan where toddlers are more at risk of suffering from diarrhea. (Siziya et al. 2013) Children with poor nutritional and immune status and living in sanitary and bad water quality are more susceptible to diarrhea than other children. (The United Nations Children's Fund (UNICEF)/World Health Organization (WHO) 2009) Adults are more likely to be caused by a lack of awareness of personal sanitation hygiene due to lack of knowledge or negligence. (Mashoto KO et al. 2014)

Research by Aini (2016) in Puskesmas Banyuasin Purworejo District showed different results, that the incidence of diarrhea in children under five years of $4.2 \%$ (26 of 623 infants) and not found significant relationship between quality bacteriologist drinking water and the source type with the incidence of diarrhea in the child of this age group. (Aini et al. 2016) The result of the same research by 
Puspitasari (2013) which mentions that there is a link between the quality of bacteriology wells and PHBS and the incidence of water-sourced diseases in the village of Tambak Wells, Waru District, Sidoarjo, showed that diarrhea becomes The only disease suffered by the local community for the last 6 months and more suffered in the age group of 46-55 years. (Puspitasari \& Mukono 2013) In addition, the research is also not found a significant relationship between bacteriological quality and healthy behavior with the incidence of water borne disease. (Puspitasari \& Mukono 2013)) However, both the age group of toddlers and the age group of 46-55 years are equally vulnerable to diseases such as diarrhea. (Puspitasari \& Mukono 2013).

In addition to the ease of access as the main reason the community switched to this drinking water depo, is that public perception of refill water is worth to consume and often has been through several processes of filtration, cleansing and sterilization before sold to consumers. This is the cause of most respondents admitted that there is no need to cultivate drinking water and drink immediately. But in fact, many of the Depo drinking water providers do not carry out the standard procedures set on the appliance, the lack of knowledge of depo officers in terms of hygiene and sanitation are indicated by Wash your hands before serving, do not wash properly gallon of consumers before charging, as well as many found Depo owners provide interservice by using jerry cans. In observation we also found a number of gallons of depo owners who used the condition is not clean and mossy. (Andiarsa et al. 2018)

The results of the observation were supported by the results of Astuti Study (2014) which reported that there is a meaningful correlation between the quality of raw water sources, quality of filters, and disinfectant tools with the amount of bacterial pollutants on water from the Depo drinking water. ((Astuti \& Suwondo
2014) Likewise, Pradana's research (2013) shows that 5 of the 9 Depo drinking waterfilled refills that have not been eligible for eligibility are still not fully implementing the operational standard procedure (SOP) Maintenance tools. (Pradana \& Bowo Djoko Marsono 2013) According to Raksanagara (2018), there are internal factors that affect the production quality of the Depo refill water such asthe Depo officers, procedures of use of tools, infrastructure, and hygiene levels, while the external factors are Government supervision, sanctions, and cooperation (Raksanagara et al. 2018).

Studies of the quality of chemical, physical, and bacteriological depo drinking water have been done before. The quality of drinking water from the depo of drinking water that qualifies for physical and chemical examinations has not fully guaranteed a good bacteriological quality. Most studies have reported that this drinking water source has been contaminated by the koliform bacteria, which is one of the quality standards of drinking water worthiness. Research by Fitri Mairizki (2017) found that out of 10 samples of drinking water from Depo that have been compliant with physical and chemical quality standards, are known to be contaminated by the bacteria so that it is not worth consumption. (Mairizki 2017)The same results were also shown from Wandrivel's research (2012) and Rosita (2014) which found about $50 \%$ of refill water samples containing E. coli and Coliform. (Wandrivel et al. 2012; Rosita 2014)

Depo drinking water is mushed in the regency of Tanah Bumbu. Refill drinking water is the third largest source of drinking water in Indonesia that is widely used in communities with a percentage of 17.2\%. (Ministry of Health 2011; Wandrivel et al. 2012) This business has expanded and become the main focus of the source of income for small entrepreneurs and becomes a fundamental need for consumers. (Bayer, 2013) This 
business should be able to support the micro economy for the small community, affordable prices and the ease offered directly can drive the wheels of the economy in the community. (Magtibay 2004) This Depo activity also changes the pattern of consumption of drinking water strategically to the family based on the source of water and its management. (Andiarsa et al. 2018)

The result of Depo Water sample inspection illustrates that there is still a lack of concern from business owners about the quality management of products offered. In Permenkes No. 34 year 2014 require that every DEPO entrepreneur drinking water guarantees the resulting drinking water meets the standard quality standards or drinking water quality requirements according to the provisions of the prevailing legislation. (Ministry of Health, 2014) This is due to the lack of compliance of business owners in carrying out procedures for the use of drinking water filling machines and rules established by local governments related to the management of refill drinking water (observation results).

In general, there is a wide shifting behavior pattern of society in getting access to clean water especially drinking water. Getting a decent source of drinking water is a human right. (Anand 2007; Mirosa \& Harris 2012) The utilization of refill water has expanded in communities replacing groundwater as their drinking water. Based on the results of this study also known that there is a tendency of diarrhea sufferers who use unprotected drinking water does not cultivate water before consumption. This result is in accordance with the results of the study of household water in Bandung where the results of microbiological examination showing the refills of respondents have the highest potential danger number against health standards. (Iqbal et al. 2015) Although the research categorizes drinking water refill is a source of drinking water is laik/protected (improved). (Iqbal et al. 2015)

Ananda (2017) in a different research found a significant correlation between water treatment factors from the well dig with the prevalence of diarrhea, people who did not cultivate the water before consuming are 9 times more risky to be exposed to diarrhea (Ananda 2017).

The behaviour to cultivate drinking water before consumption is very likely to be influenced by the level of public knowledge to diarrhea. Our previous research shows that mother knowledge has a significant relationship to the pervalency of diarrhea, and the behavior of drinking water is also associated with higher incidence of diarrhea. Water treatment is one of the attempts to kill bacteria that pollute the water until it is feasible and safe to consume (Herlambang, 2010).

The results of a different study by Puspitasari (2016) showed that from 34 samples of water wells in the village of Karanglawas district that does not meet the requirements of bacteriological, is known to have no significant relationship with the number of cases of diarrhea. (Puspitasari \& Anwar 2016) The difference in such results can be caused by thirty-four samples of water that are examined not only from diarrhea sufferers but also other communities in general are healthy. (Puspitasari \& Anwar 2016) In addition, the well-dug wells are not described specifically whether shielded or unprotected. (Puspitasari \& Anwar 2016) Almost all sources of drinking water have the possibility of polluted by Coliform bacteria, no exception water wells of piping such as wells or refill water (Puspitasari \& Anwar 2016).

Some of the data and facts of some research results do show differences in results. Nevertheless, it is generally evident that there is a tendency to shift people's behaviour toward the access to drinking water, and how they manage the water based on the source of water they get. Drinking water that is increasingly 
widespread use in the community is not accompanied by the improvement of the quality of service and products produced can cause various health problems one of which is diarrhea. Public knowledge about the safety of consumption of drinking water from the Depo drinking water is still very limited and need to get attention of all parties especially the health and industry sectors. This commitment needs to be improved as a best effort in changing the behaviour of all parties involved in the dissemination of drinking water and sanitation resources (Inauen et al. 2014).

\section{CONCLUSION}

Community behaviour of Tanah Bumbu district in drinking water access has shifted to the consumer of rechargeable water in addition to using groundwater source. People also feel confident not to cultivate drinking water before consumption.

It is recommended to provide increased understanding to Depo entrepreneurs to always follow the standard procedures of tool use and adhere to rules related to the management of drinking water refill. Regular monitoring and supervision of the quality and safety of rechargeable water products can reduce the risk of health problems due to consuming this water. Conduct regular health promotion regarding the importance of boiling water first before drinking especially water from the depo drink water.

\section{REFERENCE}

Aini, N., Raharjo, M. \& Budiono, 2016. Hubungan Kualitas Air Minum dengan Kejadian Diare pada Balita di Wilayah Kerja Puskesmas Banyuasin Kecamatan Loano Kabupaten Purworejo. Jurnal Kesehatan Masyarakat, 4(1), pp.399-406.

Anand, P.B., 2007. Right to water and access to water: an assessment. Journal of International Development, 19(4), pp.511-526. https://doi.org/10.1002/jid.1386

Ananda, K.R., 2017. Hubungan pengolahan air sumur gali dengan kejadian diare di wilayah TPA Mara Fajar Pekanbaru. Universitas Sumatera Utara.

Andiarsa, D., Setianingsih, I., Setyaningtyas, D.E., et al., 2016. Analisis faktor penyebab diare di Kabupaten Tanah Bumbu dengan pendekatan Geographical Information System (GIS). (Report), Batulicin.

Andiarsa, D. et al., 2018. Spatial effect of refilling drinking water depos toward diarrhea in Pagatan, Sub District of Kusan Hilir, Tanah Bumbu District, South Kalimantan. In 4th International Conference of Public Health. pp. 40-48. https://doi.org/10.17501/24246735.20 18.4105

Andiarsa, D., Setianingsih, I., Fadilly, A., et al., 2016. Uji Terhadap Cara Penyediaan Air Isi Ulang pada Tanah Bumbu. Jurnal Sel, 3(1), pp.24-30.

Andiarsa, D., Setianingsih, I. \& Sulasmi, S., 2017. Kebijakan pengendalian diare berdasarkan analisis spasial faktor penyebab diare di Kabupaten Tanah Bumbu. Jurnal Kebijakan Pembangunan, 12(1), pp.9-21.

Apriliana, E., Ramadhian, M. \& Gapila, M., 2014. Bacteriological quality of refill drinking water at refill drinking water depos in Bandar Lampung. Juke, 4(7), pp.142-146.

Astuti, S.D. \& Suwondo, A., 2014. FaktorFaktor Yang Berhubungan Dengan Angka Kuman Dalam Air Produk Air Minum Isi Ulang di Pemalang. Jurnal Kesehatan Lingkungan Indonesia, 13(1), pp.20-25.

Bayer, R., 2013. Drinking water as a source of income. Lund University.

Birawida, A.B., Selomo, M. \& Mallongi, A., 2018. Potential hazards from 
hygiene, sanitation and bacterium of refill drinking water at Barrang Lompo island (water and food safety perspective) Potential hazards from hygiene, sanitation and bacterium of refill drinking water at Barrang Lompo island (water. IOP Conf. Series: Earth and Environmental Science, $\quad 157, \quad$ p.12034. https://doi.org/10.1088/1755$1315 / 157 / 1 / 012034$

Bwogi, J. et al., 2016. The epidemiology of rotavirus disease in under-fiveyear-old children hospitalized with acute diarrhea in central Uganda, 2012-2013. Archives of Virology, 161(4), pp.999-1003. https://doi.org/10.1007/s00705-0152742-2

Cairncross, S. \& Valdmanis, V., 2006. Water Supply, Sanitation, and Hygiene Promotion. In Disease Control Priorities in Developing Countries. pp. 771-792. https://doi.org/10.1596/978-0-82136179-5/Chpt-41

Clasen, T., 2015. Household Water Treatment and Safe Storage to Prevent Diarrheal Disease in Developing Countries. Current environmental health reports, 2(1), pp.69-74.

https://doi.org/10.1007/s40572-0140033-9

Farthing, M. et al., 2013. Acute Diarrhea in Adults and Children. Journal of Clinical Gastroenterology, 47(1), pp.12-20.

https://doi.org/10.1097/MCG.0b013e 31826df662

Godana, W. \& Mangiste, B., 2013. Environmental Factors Associated with Acute Diarrhea among Children Under Five Years of Age in Derashe District, Southern Ethiopia. Science Journal of Public Health, 1(3), p.119. https://doi.org/10.11648/j.sjph.20130 103.12

Huda, T.M.N. et al., 2012. Interim evaluation of a large scale sanitation, hygiene and water improvement programme on childhood diarrhea and respiratory disease in rural Bangladesh. Social Science \& Medicine, 75(4), pp.604-611. https://doi.org/10.1016/j.socscimed.2 011.10 .042

Inauen, J., Tobias, R. \& Mosler, H.-J., 2014. The role of commitment strength in enhancing safe water consumption: Mediation analysis of a cluster-randomized trial. British Journal of Health Psychology, 19(4), pp.701-719.

Iqbal, M. et al., 2015. Improved but not always safe: A microbial water quality analysis in Bandung PeriUrban Households. In The 5th Environmental Technology and Management Conference. Bandung, pp. 1-8.

Keman, S., 2005. Quality of Refilled Drinking Water in Surabaya City. Folia Medica Indonesiana, 41(1), pp.29-35.

Ministry of Health, 2011. Basic Health Research (RISKESDAS) 2010 (Report), Jakarta.

Ministry of Health, 2008. Riskesdas 2007 (Laporan Nasional), Jakarta: Badan Litbang Kesehatan.

Ministry of Health, 2014. Peraturan Menteri Kesehatan tentang Higiene Sanitasi Depo Air Minum,

Kurniatri, A.A., 2011. Quality of refill drinking water in Greater Jakarta in 2010. Health Science Indonesia, 2(2), pp.77-80.

Litbangkes, 2014. Riskesdas Dalam Angka, Kalimantan Selatan 2013, Jakarta: Penerbit Badan Litbangkes.

Lucas, P.J., Cabral, C. \& Colford, J.M., 2011. Dissemination of drinking water contamination data to consumers: A systematic review of impact on consumer behaviors. PLoS ONE, 6(6). https://doi.org/10.1371/journal.pone.0 021098

Magtibay, B.B., 2004. Water refilling 
station: an alternative source of drinking water supply in the Philippines. In 30th WEDC International Conference, Vientiane, Lao PDR, 2004. pp. 590-593.

Mairizki, F., 2017. Analisis Kualitas Air Minum Isi Ulang di Sekitar Kampus Universitas Islam Riau. Jurnal Katalisator, 2(1), pp.9-19. https://doi.org/10.22216/jk.v2i1.1585

Majuru, B., Jagals, P. \& Hunter, P.R., 2012. Assessing rural small community water supply in Limpopo, South Africa: Water service benchmarks and reliability. Science of The Total Environment, 435-436, pp.479-486.

https://doi.org/10.1016/j.scitotenv.20 12.07.024

Mashoto KO et al., 2014. Prevalence, one week incidence and knowledge on causes of diarrhea: household survey of under-fives and adults in Mkuranga district, Tanzania. BMC Public Health, 14(985), pp.1-8. https://doi.org/10.1186/1471-245814-985

Mekonnen, M.M. \& Hoekstra, A.Y., 2014. Water footprint benchmarks for crop production: A first global assessment. Ecological Indicators. https://doi.org/10.1016/j.ecolind.2014 .06 .013

Mirosa, O. \& Harris, L.M., 2012. Human Right to Water: Contemporary Challenges and Contours of a Global Debate. Antipode, 44(3), pp.932-949. https://doi.org/10.1111/j.14678330.2011.00929.x

Parimin, Yusuf, M. \& Putra, M.U.M., 2016. Analisis Faktor-Faktor yang Mempengaruhi Permintaan Air Minum Isi Ulang di Kota Binjai. Jurnal Wira Ekonomi Mikroskil, 6(2), pp.103-112.

https://doi.org/10.35906/jep01.v2i1.1 53

Pradana, Y.A. \& Bowo Djoko Marsono, 2013. Uji Kualitas Air Minum Isi Ulang di Kecamatan Sukodono,
Sidoarjo Ditinjau dari Perilaku dan Pemeliharaan Alat. Jurnal Teknik Pomits, 2(2), pp.83-86.

Puspitasari, A. \& Anwar, C., 2016. Hubungan Sanitasi Sumur Gali dan Kualitas Bakteriologis dengan Prevalensi Diare Infeksi di Desa Pangebatan Kecamatan Karanglewas Kabupaten Banyumas Tahun 2016. Keslingmas, 35, pp.278-296.

Puspitasari, S. \& Mukono, J., 2013. Hubungan Kualitas Bakteriologis Air Sumur dan Perilaku Sehat dengan Kejadian Waterborne Disease di Desa Tambak Sumur, Kecamatan Waru, Kabupaten Sidoarjo. Jurnal Kesehatan Lingkungan, 7(1), pp.7682.

Raksanagara, A.S. et al., 2018. Aspek Internal dan Eksternal Kualitas Produksi Depo Air Minum Isi Ulang: Studi Kualitatif di Kota. MKB, 50(1), pp.53-60.

https://doi.org/10.15395/mkb.v50n1.1 143

Rosita, N., 2014. Analisis Kualitas Air Minum Isi Ulang Beberapa Depo Air Minum Isi Ulang ( DAMIU ) di Tangerang Selatan. Jurnal Kimia Valensi, 4(2), pp.134-141. https://doi.org/10.15408/jkv.v0i0.361 1

Rumondor, P.P., Porotu'o, J. \& Waworuntu, O., 2014. Identifikasi bakteri pada depo air minum isi ulang di Kota Manado. e-Biomedik, 2(2), pp.1-4. https://doi.org/10.35790/ebm.2.2.201 4.5518

Sima, L.C. et al., 2012. Relationship between use of water from community-scale water treatment refill kiosks and childhood diarrhea in Jakarta. American Journal of Tropical Medicine and Hygiene, 87(6), pp.979-984.

https://doi.org/10.4269/ajtmh.2012.12 $-0224$

Sima, L.C. \& Elimelech, M., 2013. More than a drop in the bucket: 
Decentralized membrane-based drinking water refill stations in Southeast Asia. Environmental Science and Technology, 47(14), pp.7580-7588.

https://doi.org/10.1021/es304384n

Siziya, S., Muula, a S. \& Rudatsikira, E., 2013. Correlates of diarrhoea among children below the age of 5 years in Sudan. African health sciences, 13(2), pp.376-83.

https://doi.org/10.4314/ahs.v13i2.26

The United Nations Children's Fund (UNICEF)/World Health Organization (WHO), 2009. Diarrhoea: Why Children are Still Dying and What can Be Done,

Tombeng, R.B., Polii, B. \& Sinolungan, S., 2013. Analisis Kualitatif kandungan Escherichia coli dan Coliform pada 3 depo air minum isi ulang di Kota Manado. Jurnal

Kesehatan Masyarakat Universitas Sam Ratulangi, 1(7).

Traoré, D. et al., 2013. Water quality and health in a Sahelian semi-arid urban context: An integrated geographical approach in Nouakchott, Mauritania. Geospatial Health, 8(1), pp.53-63. https://doi.org/10.4081/gh.2013.54

Vandepitte, J. et al., 2011. Basic Laboratory Procedures in Clinical Bacteriology 2nd ed. D. Susanto, ed., Jakarta: EGC.

Walter, C.T., Kooy, M. \& Prabaharyaka, I., 2017. The role of bottled drinking water in achieving SDG 6.1: an analysis of affordability and equity from Jakarta, Indonesia. Journal of Water, Sanitation and Hygiene for Development, 7(4), pp.642-650. https://doi.org/10.2166/washdev.2017 .046

Wandrivel, R., Suharti, N. \& Lestari, Y., 2012. Kualitas air minum yang diproduksi depo air minum isi ulang di Kecamatan Bungus Padang berdasarkan persyaratan mikrobiologi. Jurnal Kesehatan Andalas, 1(3), pp.129-133.
WHO \& UNICEF, 2015. Wash post-2015: proposed targets and indicators for drinking-water,sanitation and hygiene. , (April 2014), pp.1-12.

Wong, L.T. \& Mui, K.W., 2008. Epistemic water consumption benchmarks for residential buildings. Building and Environment, 43(6), pp.1031-1035. https://doi.org/10.1016/j.buildenv.200 6.11 .040 